\title{
BACK SURFACE CELL STRUCTURES FOR REDUCING RECOMBINATION IN CZ SILICON SOLAR CELLS
}

\author{
Richard R. King, Kim W. Mitchell, and James M. Gee \\ Siemens Solar Industries, 4650 Adohr Lane, P.O. Box 6032, Camarillo, CA 93011 U.S.A. \\ - Sandia National Laboratories, P.O. Box 5800, Albuquerque, NM 87185-0752 U.S.A.
}

\begin{abstract}
Mass-produced terrestrial CZ silicon solar cells are currently entering the domain in which bulk diffusion length is comparable to the cell thickness, so that recombination at the back surface can have a significant effect on device performance. Three manufacturable processes that address the problem of back recombination are examined here: boron diffusion from a deposited doped $\mathrm{SiO}_{2}$ layer[1]; A-alloyed layers using screen-printed paste[2]; and use of a collecting $n$ layer on the back interdigitated with the positive electrode[3,4]. 104- $\mathrm{cm}^{2}$ cells fabricated at Siemens Solar Industries using these back surface structures are characterized by current-voltage, spectral response, photoconductivity decay, and SiMS measurements.
\end{abstract}

\section{INTRODUCTION}

As the substrate thickness of mass-produced silicon solar cells is reduced to minimize costs, recombination at the back becomes increasingly impotant to the device performance. By vitue of their greater diffusion lengths, single-crystal $\mathrm{CZ}$ Si cells are more sensitive to back surface recombination than are multicrystalline $S i$ cells at the same thickness. High-throughput fabrication methods to reduce back recombination are becoming increasingly important for mass-produced $\mathrm{CZ}$ cells.

Among the approaches being studied at Siemens Solar to reduce back surface recombination are: offfusion from a borosilicate glass doping source[1]; alloying with screen-printed A[2]; and formation of $n$ type regions on the back, interdigitated with p-type areas, that help collect minority electrons in the p-yype substrate[3,4]. Cells with $104-\mathrm{cm}^{2}$ area have been fabricated with each of these processes on commercial C2 material grown at Siemens Solar Industries (SSI). The boron diffusions are characterized by microwave photoconductivity decay ( $\mu$ W-PCD) measurements[5], and by quantum efficiency measurements with light incident on the front and on the back. A-doped layers formed by alloying with screen-printed $A$ paste are characterized by SIMS. The degree of phosphorus compensation in the $p^{-}$- Al-doped layer, eaused by alloying through a phosphorus diffusion, is also measured by SIMS. Cells with collecting $n$ "regions on the back in addition to the front $n^{*}$ emitter, fabricated on $104-\mathrm{cm}^{2}$ SSI CZ substrates using only screen-printing patteming technology, exhibit current densifies up to $35.9 \mathrm{mAvm}^{2}$. About $5 \%$ of this curent is contributed by the back $n^{*}$ regions which cover $-60 \%$ of the back surface in these non-optimized cells. All three of the above methoos add a minimal number of steps to the cell fabrication sequence, and use inexpensive, robust processes such as screen-printing. These are key considerations for applying a candidate process in a mass-production environment.

\section{BORON-DOPED LAYERS}

For metal-contacted regions on the back, deeper boron diffusions result in a lower emitter saturation current density $J_{0}$ of the doped layer. However. processing times and temperatures should ideally be kept low for $C Z$ silicon, to avoid degradation of the bulk lifetime. This results in a trade-off between the bulk lifetime and the $J_{0}$ of the metal-contacted portion of the boron-doped layer on the back. If a large fraction of the back is oxide-passivated, the $J_{0}$ can be acceptably low even for shaliow diffusions, at least for untextured surfaces[1].

Table 1 gives the values of $J_{0}$, measured by $\mu W$ PCD at Sandia. for boron diffusions made at SSI under processing conditions suitable for maintaining bulk lifetime in $\mathrm{CZ}$ solar cells. These PCD test structures have intrinsic substrates, and had boron-doped $\mathrm{SiO}_{2}$ deposited on both sides at Sandia. Measured values of the textured $n^{\circ}$ emitter $J_{0}$ are also listed in Table 1 . The effective surface recombination velocity is calculated from the measured $J_{0}$ values, using $n_{1}\left(25^{\circ} \mathrm{C}\right)=8.70 \times$ $10^{9} \mathrm{~cm}^{3}[6]$, and $N_{\alpha}=1.5 \times 10^{16} \mathrm{~cm}^{3}$. Values of $\mathrm{s}_{\pi}$ less than the value of $D /$ for minority carriers in the substrate, typically about $1500 \mathrm{~cm} / \mathrm{s}$ for $S S I \mathrm{CZ}$ cells, result in reduced cell recombination as the cell thickness is decreased.

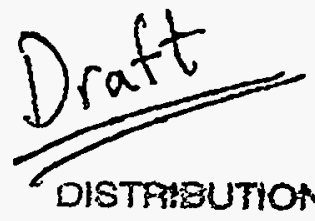

This work was suponted by the United States Department of Energy under Contract DE-ACD4-94AL85000. 


\section{DISCLAIMER}

This report was prepared as an account of work sponsored by an agency of the United States Government. Neither the United States Government nor any agency thereof, nor any of their employees, makes any warranty, express or implied, or assumes any legal liability or responsibility for the accuracy, completeness, or usefulness of any information, apparatus, product, or process disclosed, or represents that its use would not infringe privately owned rights. Reference herein to any specific commercial product, process, or service by trade name, trademark, manufacturer, or otherwise does not necessarily constitute or imply its endorsement, recommendation, or favoring by the United States Government or any agency thereof. The views and opinions of authors expressed herein do not necessarily state or reflect those of the United States Government or any agency thereof. 


\section{DISCLAIMER}

Portions of this document may be illegible electronic image products. Images are produced from the best available original document. 
Table 1: Measured values of the saturation curent density $J_{0}$ for samples diffused at SSI.

\begin{tabular}{|c|c|c|c|}
\hline PCD Sample Structure & Surface Condition & $\begin{array}{c}J_{0} \text { at } 25^{\circ} \mathrm{C} \text { from } P C D \\
\left(10^{-13} \mathrm{Nem}\right)\end{array}$ & $\begin{array}{c}s_{\infty}=J_{0}\left(N_{A} / q n_{l}^{2}\right) \\
(c m / s)\end{array}$ \\
\hline \multirow[t]{3}{*}{ pip" } & bare, textured & 9.4 & 1170 \\
\hline & bare, untextured & 8.9 & 1100 \\
\hline & oxide pass., untextured & 1.9 & 240 \\
\hline \multirow[t]{2}{*}{ nin* } & bare, textured & 10.7 & 1320 \\
\hline & oxide pass., textured & 7.3 & 900 \\
\hline
\end{tabular}

Fig. 1 shows the measured extemal quantum efficiency for light incident on the front and on the back of two SSI CZ cells with $228 \pm 10 \mu \mathrm{m}$ substrates, one with a boron diffusion on the back, and the other with no boron diffusion. The reduced back surface recombination for the boron-diffused cell is evident from the greater back response of that cell, especially at the shorter wavelengths for which charge carriers are being generated near the back surface.
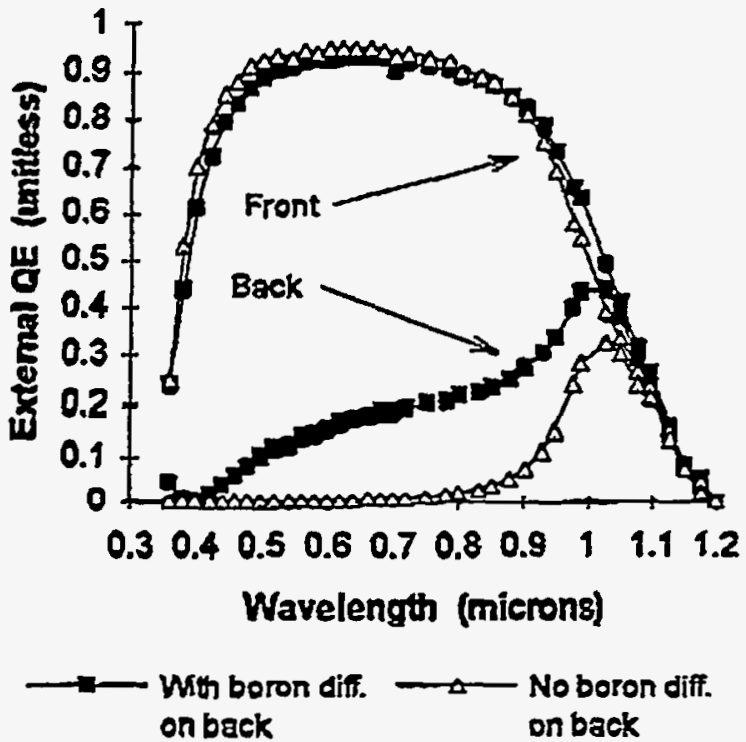

Fig. 1: External quantum efficiency measured with light incident on the back and on the front of SSI CZ cells with two different back conditions. The cell with a boron diffusion on the back has a much greater back response at short wavelengths.

\section{AIALLOYED LAYERS}

Auminum alloying provides an altemative to shallow, heavily-doped boron diffusions, by forming a $p^{+}$layer which can be many microns deep, but which has $a$ relatively low dopant concentration. Fig. 2 shows the SIMS profile of an A-doped layer formed by alloying screen-printed $\mathrm{A}$ paste with an SSI CZ Si substrate. The peak $A$ concentration is $-5 \times 10^{18} \mathrm{~cm}^{-3}$, and the thickness of the $p^{*}$ layer is $-13 \mu \mathrm{m}$. In practice, $A$ is often alloyed through a phosphorus-doped layer, which could potentially compensate the Al-doped Si layer pegrown from the Al meit. Fig. 2 also plots the SIMS phosphons profile for the same Al-alloyed sample, showing that the phosphorus, while present in the regrown layer, has a concentration less than one-tenth that of the aluminum.
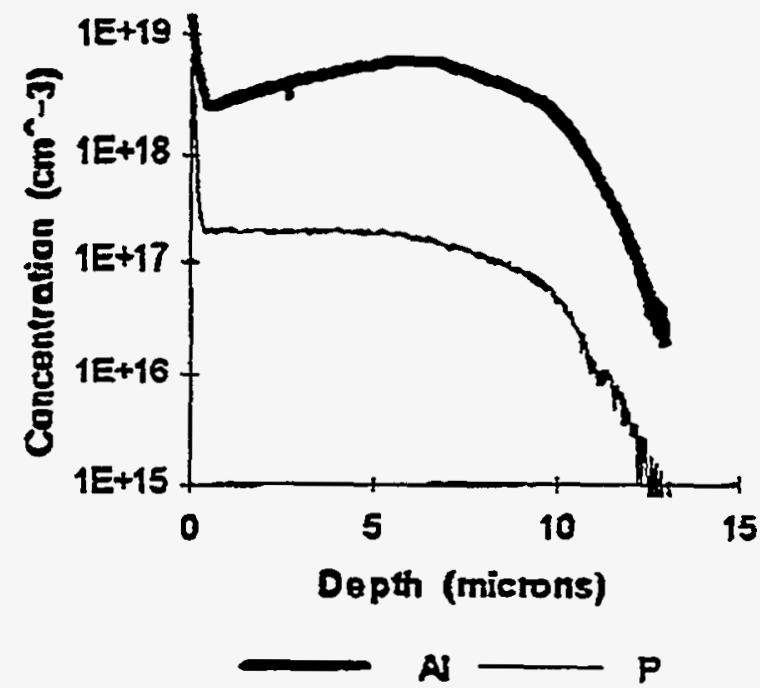

Fig.2: Auminum and phosphorus SIMS profiles for an alloyed layer formed using screen-printed $\boldsymbol{A}$. 
Iable 2: Measured parameters for $104-\mathrm{cm}^{2}$ SSI CZ cells with screen-printed A alloyed on the back, and for controls with standard processing. The shaded area gives the percent difference between a given experimental group and the $284 \mathrm{\mu m}$ group with the standard process.

\begin{tabular}{|c|c|c|c|c|c|c|c|}
\hline \multirow{2}{*}{$\begin{array}{c}\text { Cell } \\
\text { Process }\end{array}$} & \multirow{2}{*}{$\begin{array}{l}\text { Number } \\
\text { of cells } \\
\text { in group }\end{array}$} & \multicolumn{6}{|c|}{ Average measured parameters for each experimental group: } \\
\hline & & $\begin{array}{c}\text { Thickness } \\
(\mu \mathrm{m})\end{array}$ & $\begin{array}{l}V_{\infty} \\
(m V)\end{array}$ & $\begin{array}{c}J_{\infty} \\
\left(m \mathbb{N} \mathrm{cm}^{2}\right)\end{array}$ & FF & $\begin{array}{l}\text { Eff. } \\
(\%)\end{array}$ & $\begin{array}{c}\text { Ext. QE at } \\
946 \mathrm{~nm} \\
\text { (act.area) }\end{array}$ \\
\hline \multirow{4}{*}{$\begin{array}{c}\text { Screen- } \\
\text { printed } \\
\text { Al } \\
\text { alloyed } \\
\text { on back }\end{array}$} & \multirow[t]{2}{*}{8} & 224 & 609 & 33.3 & 0.752 & 15.2 & 0.786 \\
\hline & & 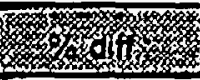 & 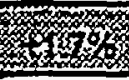 & 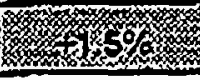 & 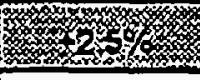 & 嬨 & 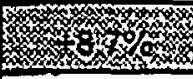 \\
\hline & \multirow[t]{2}{*}{4} & 298 & 603 & 33.0 & 0.753 & 15.0 & 0.791 \\
\hline & & 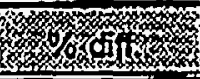 & O. & 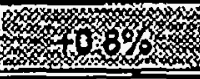 & 8 & 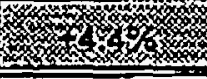 & 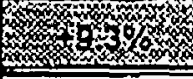 \\
\hline \multirow{4}{*}{$\begin{array}{l}\text { Standard } \\
\text { process }\end{array}$} & \multirow[t]{2}{*}{7} & 209 & 589 & 31.9 & 0.734 & 13.8 & 0.666 \\
\hline & & $x$ & s. & $z$ & 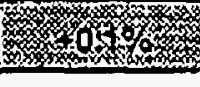 & 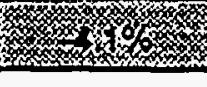 & 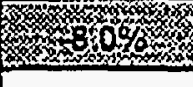 \\
\hline & \multirow[t]{2}{*}{13} & 284 & 598 & 32.8 & 0.734 & 14.4 & 0.724 \\
\hline & & & & & & & o \\
\hline
\end{tabular}

SSI cells with this $A \mathrm{~A}$ doping profile on the back have substantially higher values of $V_{\alpha}$ and $J_{x}$, as expected for this classic back-surface-field formation process. Table 2 shows the average measured cell performance for $104 \mathrm{~cm}^{2}$ cells. Cells with an Al-alloyed back and $224 \mathrm{\mu m}$ substrate thickness have an average efficiency of $15.2 \%$, or 5.8 relative \% higher than for $284 \mu \mathrm{m}$ cells with the standard process. The illuminated $\mathrm{H}-\mathrm{V}$ parameters were measured at SSI at $25^{\circ} \mathrm{C}, 0.100$ W/cm² AM1.5G, using a reference cell calibrated at Sandia National Labs. Active-area, extemal quantum efficiency measurements were made at SSI, using reference detectors that were also calibrated at Sandia.

\section{TRANSISTORLIKE STRUCTURE}

Cells with three terminals (the normal front $n^{\circ}$ contact, the back contact to the p-type base, pius an additional contact to an $n^{\circ}$ region on the back intercigitated with the positive back electrode) have demonstrated enhanced current densities, both for front illumination and for the case in which light is incident on the rear of the cell[3,4]. 104-cm² cells fabricated at SS] with a collecting $n^{+}$layer on the back have current densities of up to $35.9 \mathrm{mAcm} \mathrm{m}^{2}$ when illuminated from the front only. Accounting for a $9 \%$ grid shadowing loss, this translates to an active-area $\mathrm{J}_{x}$ of $39.4 \mathrm{~mA} \mathrm{~cm}^{2}$.

Fig. 3 shows the light I-V characteristics of a cell from a preliminary run of transistor-like cells, made with only screen-printed patteming. The measurements were made with two electrode interconnection

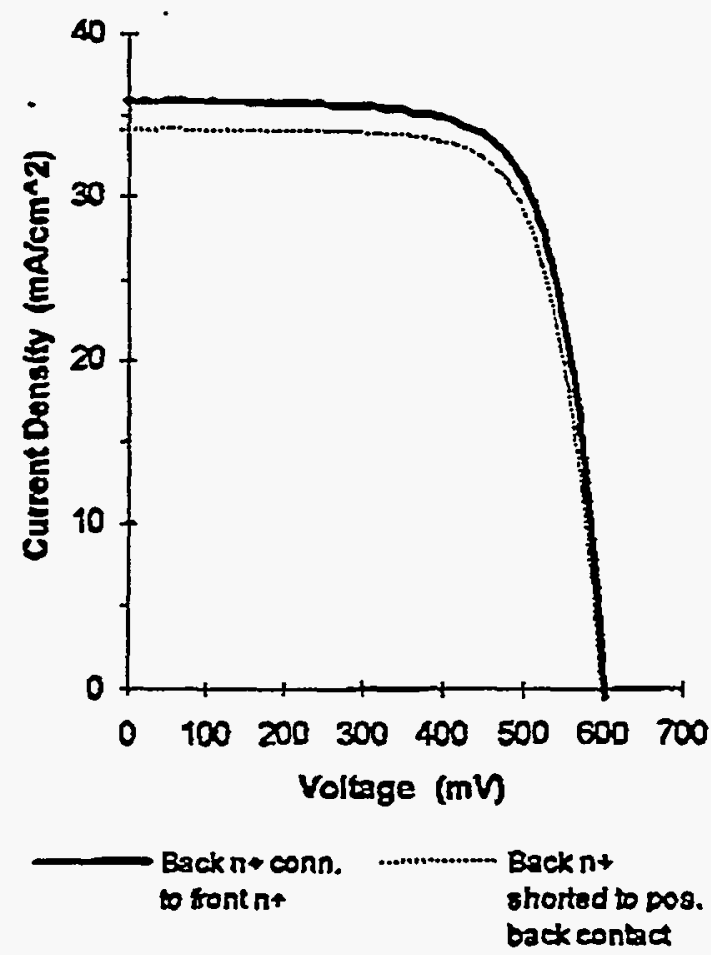

Fig. 3: Uight I-V curves for a transistor-fike cell with $n^{*}$ collecting regions on the back, for two electrode interconnection configurations. Light is incident on the font of the cell only. 
Table 3: Measured IV parameters for a cell with back $n^{\circ}$ collecting regions fabricated on SSI C2 silicon using screen-printing methods.

\begin{tabular}{|c|c|c|c|c|}
\hline Measurement Configuration & $\begin{array}{c}V_{\infty} \\
(\mathrm{mV})\end{array}$ & $\begin{array}{c}\text { Jse } \\
(\mathrm{mA} / \mathrm{cm} 2)\end{array}$ & FF & $\begin{array}{c}\text { Efficiency } \\
(\%)\end{array}$ \\
\hline Back $n+$ cosnected to front $n+$ emitter & 602 & 35.9 & 0.719 & 15.5 \\
\hline Back $n+$ shorted to posibive back contact & 597 & 34.1 & 0.727 & 14.8 \\
\hline
\end{tabular}

configurations: with the back $n^{*}$ regions externally connected to the front $n^{+}$emitter; and with the back $n^{*}$ regions shorted to the positive back electrode. The light I-V parameters for these two configurations are shown in Table 3 . The primary effect of the collecting $n+$ layer on the back is to increase Jsc by about $5 \%$ for these cells with $1.0 \Omega \mathrm{cm}, 300 \mu \mathrm{m}$ thick substrates. The light I-V measurements were again made at SSI at 0.100 $W / \mathrm{cm}^{2} \mathrm{AM} 1.5 \mathrm{G}$, as determined by a reference cell calibrated at Sandia. Because of the nature of the back contact, the cell was not resting on a temperaturecontrolled chuck, so the cell temperature of $25^{\circ} \mathrm{C}$ was determined from the $V_{\infty}$ for the cosfiguration with the back $n^{+}$region shorted to, the positive back contact.

These cells were designed with a faity coarse pattern on the back, with a center-to-center spacing between fingers of flke polarity of $0.254 \mathrm{~cm}$, to make the alignment of the interdigitated back pattems as robust as possible. Large alignment folerances increase the distance between the fingers of the positive electrode, increasing substrate resistive losses and decreasing fill factor, and also require minority electons in the substrate to diffuse farther on average to reach a collecting $n^{*}$ region on the back. Improved alignment mechanisms can vastly improve the accuracy of the print positton, allowing higher cell efficiencies.

\section{SUMMARY}

A variety of simple methods exist which hold the potential to increase the efficiency of mass-prodiced $\mathrm{CZ}$ silicon solar cells by $5 \%$ or more, impacting the cost per watt of photovoltaic power by a similar fraction. In order to make these processes cost-effective, it is vital that the methods used to implement them are as simple as possible, using robust, high-throughput methods such as screen-printing for cell patterning. Commercial CZ cells, with present substrate thicknesses typically 1 to 2 times their diffusion length, are currenty poised to take advantage of both back-surface field structures and collecting $n^{*}$ back regions. On thinner substrates, the performance advantages are even greater.

\section{ACKNOWLEDGMENTS}

The authors would like to thank the researchers at Sandia National Laboratories, especially P. Basore and. B. Silva, for their hard work to deposit $\mathrm{SiO}_{2}$ layers on the cells in this study, and to measure the $J_{0}$ of boron and $\mu W-P C D$. We would also like to thank R. Balanga; D. Cezar, W. Chesarek, J. Frost, T. Jester, K. Kuehi, A. Monzer, J. Schwrart, D. Tanner, B. Wieting, and the R\&D and Engineering staff at Siemens Solar for their encouragement and technical assistance.

\section{REFERENCES}

[1] R. R. King and R. M. Swanson, "Studies of Diffused Boron Emitters: Saturation Currem, Bandgap Narrowing, and Surface Recombination Velocity, "IEEE Transactions on Electron Devices, 38, 1991, Pp. 1399 1409.

[Z] P. Lölgen of al., "Aluminum Back-Surface Field Doping Profiles with Surface Recombination Velocities Below $200 \mathrm{~cm}$ s," Twenty-Third IEEE PVSC, 1993, pp. 236-242.

[3] A Cuevas, A. Luque, and J. M. Rulz, "A nipn' Double-sided Solar Cell for Optimal Static Concentration," Fourteenth IEEE PVSC, 1980, pp. 7681.

[4] T. Warabisako ot al., Bifacial Multicrystalline Silicon Solar Cells," Twenty-Third IEEE PYSC, 1993, pp. 248251.

[5] P. A. Basore and B. R. Hansen, MicrowaveDetected Photoconductivity Decay," Twenty-first IEEE PVSC, 1980, pp. 374-379.

[6] A. B. Sproul and M. A. Green, Experimental Measurement of the Intrinsic Carrier Concentration of Silicon," Twenty-first IEEE PVSC, 1990, pp. 380-385. 